\title{
NOTE ON TERMINOLOGY
}

In keeping with recent contributions to the scholarship on imperial history, I see empire not as a territory of conquest but as something defined by its various practices of control. ${ }^{1}$ In this sense the British academic world was very much part of the empire that John Darwin has called 'the Britannic experiment'; a circulating world of people, goods and ideas, which helped maintain ties between the Dominions and Britain. ${ }^{2}$ The universities founded in the settler colonies were very much 'colonial' institutions. They were products of a proud 'colonial nationalism' that lasted beyond the achievement of 'Dominion' status, in which large numbers of those who lived in Canada, Australia, New Zealand and (to a lesser extent) South Africa, identified both with Britain and with the colony in which they were born or lived. Universities fostered these ties: they extended dominion over the soil and over its original inhabitants by sanctioning what counted as knowledge and by providing much of the expertise needed to map and regulate and heal; and they extended dominion within the people, by shaping culture and identity. But there were other parts of the empire, which are also commonly referred to as 'colonies' - in Africa, India and South East Asia - where universities were established by British officials and more explicitly associated with the imposition of rule and the institution of foreign language and culture. The term 'colonial university' also brings with it these connotations, and it is to avoid this conflation that I frequently use the term 'settler university' and 'settler scholar'. In doing so I wish to signal that these were institutions made by colonial settlers, who saw themselves as independent and autochthonous members of a wider British community. At times I also speak of 'colonial knowledge', a term which has been the subject of lively scholarly interest, and one that is usually taken to refer to the forms of knowledge (including administrative practices, as well as classificatory processes and more traditional forms of inquiry such as history) used to maintain imperial authority. Most of the debate centres on the role played by the colonised in the production of such knowledge, but my emphasis here is looser and more in line with that employed by Saul Dubow. While acknowledging its political function and role as an instrument of power, he suggests that what he calls 'colonial local knowledge' was also 'bound up with conceptions of selfempowerment and in demonstrating one's worth to peers and betters'. ${ }^{3}$ 
This knowledge bore the marks of the environments in which it was made; environments that included the perspectives of distance, the innovations born of isolation, and the necessity of developing applied understanding in independent and growing settler communities. These were soft as well as hard forms of knowledge; forms of knowledge that, like the specimens sent to Kew Gardens in an earlier era, were of great value to modern scholarship, but that, unlike those specimens, were lodged in people and their skills and experience.

\section{Notes}

1 Jane Burbank and Frederick Cooper, Empires in World History: Power and the Politics of Difference (Princeton, NJ: Princeton University Press, 2010), $3-4,122$.

2 John Darwin, The Empire Project: The Rise and Fall of the British WorldSystem, 1830-1970 (Cambridge: Cambridge University Press, 2009), 144-79.

3 Phillip B. Wagoner, 'Precolonial Intellectuals the the Production of Colonial Knowledge,' Comparative Studies in Society and History, 45, no. 4 (2003): 783; Saul Dubow, A Commonwealth of Knowledge: Science, Sensibility, and White South Africa, 1820-2000 (Oxford: Oxford University Press, 2006), 14. 